\section{Utilization of medicines by the Brazilian population, 2003}

\author{
Características da utilização de medicamentos \\ na população brasileira, 2003
}

\author{
1 Gerência de Medicamentos, \\ Agência Nacional de Vigilância \\ Sanitária, Brasília, Brasil. \\ 2 Programa Nacional de DST \\ e AIDS, Ministério da Saúde, \\ Brasília, Brasil. \\ 3 Centro de Informação \\ Científica e Tecnológica, \\ Fundação Oswaldo Cruz, \\ Rio de Janeiro, Brasil. \\ Correspondence \\ M. F. Carvalho \\ Gerência de Medicamentos, \\ Agência Nacional de \\ Vigilância Sanitária. \\ SQN 411, Bloco F, apto. 107, \\ Asa Norte, Brasília, DF \\ 70866-060, Brasil. \\ marcelo.felga@anvisa.gov.br
}

\section{Abstract}

The aim of the present study was to characterize the utilization of medicines by the Brazilian population, using data from the Brazilian World Health Survey. Medicines were grouped according to the active pharmaceutical ingredient based on an adaptation of the World Health Organization standard list of essential medicines. The analysis included the characteristics of individuals who keep medicines at home and who had used them within the reference period (within two weeks prior to the interview), according to presence of medical prescription. Nearly half of the participants (49.0\%) reported use of medicines during the reference period. Older and wealthier individuals and those with chronic diseases or disabilities and with poor self-rated health keep and use medicines more frequently. For 25.0\% of the individuals that had used medicines during the reference period, none of the drugs had been prescribed by a health professional. Among the individuals who had medicines prescribed in the last appointment, 13.0\% were unable to obtain the prescribed medication (of these, $55.0 \%$ could not afford it). The most widely utilized group was that of the analgesics (22.0\%), and only $51.0 \%$ of the individuals using this type of medicine had received a medical prescription for it.

Drugs; Drug Utilization; Drug Prescriptions

\author{
Marcelo Felga de Carvalho 1 \\ Ana Roberta Pati Pascom 2 \\ Paulo Roberto Borges de Souza-Júnior 3 \\ Giseli Nogueira Damacena 3 \\ Célia Landmann Szwarcwald 3
}

\section{Introduction}

According to the World Health Organization (WHO), the rational use of medicines occurs when patients receive adequate medication for their clinical needs, at doses corresponding to individual requirements, and at the lowest possible cost for the patient and society 1 .

One of the most serious problems in contemporary society is the non-rational use of medicines. Currently, more than $50.0 \%$ of all medicines prescribed, dispensed, or sold are used improperly. Meanwhile, a third of the world population lacks essential drugs 1 . According to Wannmacher 2 , one of the main problems associated with irrational use is the diversity of available pharmaceutical products which, together with the high frequency of new discoveries in the field, facilitates over-consumption by some, while failing to reach those who most need medication.

In recent years, the pharmaceutical industry has experienced important growth. According to estimates by a nongovernmental organization 3, annual turnover of the world pharmaceutical market is some 406 billion dollars. However, the countries of North America and Europe plus Japan mobilize $80.0 \%$ of this market, while Africa, Asia, Latin America, and Central Asia are left with merely the remaining $20.0 \%$, even though they comprehend $80.0 \%$ of the world population. 
Viewing access to medicines both in terms of their affordability and their availability in health and pharmaceutical services 4 , the explanations for difficulties in access to essential drugs in the poor countries relate not only to the population precarious socioeconomic conditions, but also to lack of organization health services, inadequate supply system management, and irrational prescription ${ }^{2}$. As to medicine utilization, although intrinsically related to access, it also depends on individual need, and can occur simultaneously with or subsequent to access.

In the Brazilian pharmaceutical policy context, the guidelines adopted by the Ministry of Health for the industry are based on Ruling 3.916 of October 1998, namely "to guarantee the necessary safety, efficacy, and quality of medicines and to promote of rational use and universal access by the population to what are considered essential drugs". These measures have been implemented in both the public and private sectors and at different levels of health system management, and medicines are considered an essential input for full care practices of the Unified National Health System (SUS) 5.

The right to essential drugs has been a frequent issue in the debate both on the agendas of international agencies 6 and that of the Brazilian government, which has adopted various strategies to reduce the cost of medicines, including local production of generics 7 .

Difficulty in acquiring the medicines needed to treat health problems has also been the object of discussion in society, since medicines are part of citizens' daily lives and part of the family budget 8 . According to data from the $\mathrm{Na}$ tional Sample Household Survey (PNAD) in 1998, among the poorest tenth of Brazilian households, the majority of health expenses go to purchasing medicines 9 .

Studies in Brazil have demonstrated that use of medicines varies with age, sex, health conditions, and other social, economic, and demographic factors. Consumption is higher among the elderly, with two to five products used simultaneously and over-consumption of superfluous (unnecessary) medicines, but also under-utilization of essential drugs for disease control 10.

In 2003, a national household survey was conducted in Brazil, the World Health Survey (WHS), as part of a WHO project to assess health systems performance in member countries. The current study aims to characterize the utiliza- tion of medicines by the Brazilian population, using WHS data.

\section{Methodology}

The WHS was conducted in Brazil in 2003. A total of 5,000 adults (18 years and older) were interviewed. Sampling was done in three stages. In the first, 250 census tracts with probability proportional to size, explicitly stratified according to situation (urban or rural) and municipality size (<50,000 inhabitants; 50,000-399,999; and over 400,000). Socioeconomic level, defined by the mean income of heads-of-households in the tract, was used for implicit stratification.

Twenty households were randomly selected by inverse sampling in each tract and in thehousehold, one adult was selected with equiprobability among the household residents to answer the individual questionnaire.

The current analysis was done using the WHS "Medicine Inventory" module. The first question was whether some medicine was kept at home. If the answer was affirmative, the interviewer asked whether the individual had taken some medicine in the two weeks prior to the interview. If this answer was positive, the interviewer asked to see the packaging and medical prescription(s) for this medicine used in the previous two weeks. The interviewer then recorded the product's brand and/or generic name and whether the medication had been prescribed by a health professional.

In the data consolidation, the medicines were grouped according to the active pharmaceutical ingredient. The basis for the grouping was an adaptation of the WHO model list 11 . The names of all the Brazilian medicines cited by interviewees were listed and subsequently categorized by specific groups, according to the brand and/or generic name, after consulting the pharmaceutical reference catalogues Dicionário de Especialidades Farmacêuticas 12 and/or Dicionário Terapêutico Guanabara 13.

In the analysis of grouping by active ingredient, only the groups of medicines with a frequency greater than $1.0 \%$ were considered. Those with a frequency less than $1.0 \%$ were grouped in the category "others".

The groups of medicines analyzed were distributed as follows:

1. Analgesics, anti-inflammatory medicines, antipyretics, and muscle relaxants; 
2. Cardiovascular medicines (antianginal, antihypertensive, anti-arrhythmic and anti-hypotensive medicines, diuretics, statins);

3. Medicines acting on the respiratory tract (anti-asthmatics, anti-flu, nasal decongestants);

4. Psychoactive medicines (depressive orders, obsessive disorders, panic attack, bipolar disorder, generalized anxiety, and sleep disorders);

5 . Hormones, other endocrine medicines, and contraceptives (hormone, thyroid disorders, diabetes, contraceptives);

6. Anti-infectious medicines (antibiotics, antiparasitics, antivirals, antimalarials);

7. Vitamins, minerals, and nutritional supplements;

8. Herbal medicines;

9. Anticonvulsants and anti-epileptics;

10. Gastrointestinal medicines (antispasmodics, antacids, anti-ulcers, anti-emetics);

11. Other medicines (all those not classified in the groups specified above).

Since this set of data was obtained by a complex sample, combining first-stage stratification, clustering, and unequal selection probabilities, the information on selection stratum and sampling weight were incorporated into the statistical data analysis, using the SUDAAN software.

The analysis included the characteristics of persons who kept medicines at home, who had used medicines in the two weeks prior to the interview, and who had used medicines prescribed by health professionals during this reference period. The socio-demographic variables considered in the study were: age group (18-39, 40-59, 60+); sex; schooling (incomplete primary, complete primary or greater); population size of the municipality of residence $(50,000$ or fewer, 50,000 to $399,999,400,000$ and more); and number of household assets (0-3, 4-7, 8 and more), measured in an interval from 0 to 11 , ascribing one point each to the presence of a refrigerator, television set, sound system, clothes washer, dishwasher, microwave oven, wire-line telephone, cell phone, computer, one automobile, and two or more automobiles in the household.

Differences in the use of medicines were also analyzed by two measures of self-rated morbidity: self-evaluation of health status (very good or good, moderate, bad or very bad) and presence of a chronic disease or disability.

The mean numbers of medicines used in the two weeks prior to the interview were calculated for individuals who had or had not taken medicines, analyzed by all the socio-demographic variables considered in the study.

The $\chi^{2}$ heterogeneity test was used to test the differences in proportions, while the $t$ and
$F$ tests were used to test statistical differences in means.

Access to the prescribed medicines was defined by the following questions: "At your last appointment, did the health professional prescribe some medicine?". "If so, how many of these medicines were you able to obtain?" The options in this latter question were: all, the majority, very few, none. For those who were unable to obtain all the prescribed medicines, the interviewer asked the reason, among the following: cannot afford, cannot find all, did not believe they were all necessary, began to feel better, already had some of the medicines at home, others.

\section{Results}

Among the 5,000 interviewees, $71.1 \%$ reported keeping some type of medicine at home ( $\mathrm{n}=$ $3,554)$. This proportion was $76.6 \%$ and $64.6 \%$ for women and men, respectively. Among individuals 60 years and older, the percentage was $83.5 \%$, while among younger individuals (1839 years) it was $66.2 \%$. There was also an association with socioeconomic level: individuals with more schooling tended to keep medicines at home more frequently, as did those with more household assets. In municipalities with 400,000 inhabitants or more, the proportion was also significantly higher (Table 1).

In the group of individuals who rated their own state of health as good or very good, the proportion who kept some medicine at home was lower than among those who perceived their own health as bad or very bad $(67.6 \%$ and $81.4 \%$, respectively). In addition, $86.0 \%$ of individuals with some chronic disease or disability kept some type of medicine at home (Table 1).

In relation to the use of some medicine in the two weeks prior to the interview, among participants who kept medicine at home, nearly half reported use during the reference period $(49.0 \%)$. The socio-demographic characteristics of medicine utilization were similar to those obtained for individuals who kept medicines at home, except for the differences in the proportions according to schooling, which were not significant, probably due to the concentration of elderly in the group with incomplete primary schooling (Table 1). Meanwhile the differences were even more striking in the proportions of utilization analyzed according to selfrated health status. Among individuals who rated their own health as bad or very bad, $74.0 \%$ had taken some type of medicine in the previ- 
Proportion (\%) of individuals who kept some medicine at home and that had used some medicine in the two weeks prior to the interview, according to socio-demographic variables and self-rated health. Brazil, 2003.

\begin{tabular}{|c|c|c|c|c|c|}
\hline \multirow[t]{2}{*}{ Variable } & \multirow[t]{2}{*}{ Sample size (n) } & \multicolumn{2}{|c|}{$\begin{array}{l}\text { Kept some medicine } \\
\text { at home }\end{array}$} & \multicolumn{2}{|c|}{$\begin{array}{l}\text { Used some medicine in the } \\
\text { previous two weeks }\end{array}$} \\
\hline & & $\%$ & $\mathrm{p}$ value* & $\%$ & $p$ value* \\
\hline \multicolumn{6}{|l|}{ Sex } \\
\hline Male & 2,291 & 64.6 & 0.000 & 39.0 & 0.000 \\
\hline Female & 2,709 & 76.6 & & 57.2 & \\
\hline \multicolumn{6}{|l|}{ Age group (years) } \\
\hline $18-39$ & 2,633 & 66.1 & 0.000 & 38.9 & 0.000 \\
\hline $40-59$ & 1,620 & 73.4 & & 54.0 & \\
\hline 60 and over & 747 & 83.5 & & 73.0 & \\
\hline \multicolumn{6}{|l|}{ Schooling } \\
\hline Incomplete fundamental & 2,772 & 67.9 & 0.000 & 48.7 & NS \\
\hline Complete fundamental or greater & 2,227 & 75.1 & & 48.9 & \\
\hline \multicolumn{6}{|l|}{ Number of household assets } \\
\hline $0-3$ & 1,433 & 56.9 & 0.000 & 42.0 & 0.000 \\
\hline $4-7$ & 2,738 & 74.0 & & 48.9 & \\
\hline $8+$ & 775 & 87.4 & & 61.4 & \\
\hline \multicolumn{6}{|l|}{ Size of municipality (inhabitants) } \\
\hline Up to 49,999 & 1,709 & 67.6 & 0.031 & 46.8 & NS \\
\hline $50,000-399,999$ & 1,649 & 69.7 & & 48.5 & \\
\hline 400,000 or more & 1,642 & 76.1 & & 51.3 & \\
\hline \multicolumn{6}{|l|}{ Self-rated health } \\
\hline Very good/Good & 2,662 & 67.6 & 0.000 & 38.9 & 0.000 \\
\hline Moderate & 1,872 & 73.7 & & 57.0 & \\
\hline Very bad/Bad & 462 & 81.4 & & 73.8 & \\
\hline \multicolumn{6}{|l|}{ Chronic disease or disability } \\
\hline None & 3,539 & 64.9 & 0.000 & 38.1 & 0.000 \\
\hline Limiting & 965 & 86.7 & & 76.8 & \\
\hline Non-limiting & 455 & 85.6 & & 72.5 & \\
\hline Total & 5,000 & 71.1 & - & 48.8 & - \\
\hline
\end{tabular}

${ }^{*} \chi^{2}$ test for homogeneity of proportions.

ous two weeks, while in the group that rated their health as good this figure was only $38.0 \%$. In addition, $77.0 \%$ of persons with a chronic disease or disability with limitation of daily activities had used some type of medicine in the previous two weeks (Table 1).

Data in Table 2 show that elderly Brazilians (60 years or older) use an average of 1.6 types of medicine in a two-week period, varying from 1.4 among small-town residents to 1.9 among those in large municipalities. Among the elderly with no chronic disease or disability, the mean is 1.0 medicine, but this figure reaches
2.3 among those with a disease that limits daily activities. In general, women use more medication than men, whatever the age group analyzed, as do individuals with more schooling and greater wealth, defined here as the number of household assets.

Table 3 shows the distribution of use of medicines according to the existence of a medical prescription. Among persons who had used medicines during the two previous weeks, all the drugs had been prescribed by a physician for $68.0 \%$, as compared to none prescribed by a physician for $25.0 \%$. The presence of a medical 
Mean* number of medicines used in the two weeks prior to the interview, according to socio-demographic variables and self-rated health. Brazil, 2003.

\begin{tabular}{|c|c|c|c|c|}
\hline \multirow[t]{2}{*}{ Variable } & \multicolumn{3}{|c|}{ Age group (years) } & \multirow[t]{2}{*}{ Total } \\
\hline & $18-39$ & $40-59$ & $\geq 60$ & \\
\hline \multicolumn{5}{|l|}{ Sex } \\
\hline Male & 0.43 & 0.75 & 1.33 & 0.68 \\
\hline Female & 0.79 & 1.28 & 1.96 & 1.12 \\
\hline$p$ value $e^{\star \star}$ & 0.000 & 0.000 & 0.000 & 0.000 \\
\hline \multicolumn{5}{|l|}{ Schooling } \\
\hline Incomplete fundamental & 0.52 & 1.03 & 1.56 & 0.94 \\
\hline Complete fundamental or more & 0.70 & 1.09 & 2.07 & 0.88 \\
\hline$p$ value $e^{\star \star}$ & 0.000 & NS & 0.000 & NS \\
\hline \multicolumn{5}{|l|}{ Number of household assets } \\
\hline $0-3$ & 0.51 & 0.83 & 1.41 & 0.75 \\
\hline $4-7$ & 0.61 & 1.08 & 1.76 & 0.93 \\
\hline $8+$ & 0.91 & 1.25 & 1.75 & 1.14 \\
\hline$p$ value $e^{\star \star}$ & 0.000 & 0.000 & 0.009 & 0.000 \\
\hline \multicolumn{5}{|l|}{ Size of municipality (inhabitants) } \\
\hline Up to 49,999 & 0.58 & 0.98 & 1.43 & 0.85 \\
\hline $50,000-399,999$ & 0.61 & 1.03 & 1.67 & 0.88 \\
\hline 400,000 or more & 0.69 & 1.14 & 1.90 & 1.01 \\
\hline$p$ value $e^{\star \star}$ & NS & NS & 0.007 & 0.000 \\
\hline \multicolumn{5}{|l|}{ Self-rated health } \\
\hline Very good/Good & 0.52 & 0.71 & 1.08 & 0.62 \\
\hline Moderate & 0.78 & 1.20 & 1.73 & 1.13 \\
\hline Very bad/Bad & 1.08 & 1.82 & 2.18 & 1.75 \\
\hline$p$ value $e^{\star \star}$ & 0.000 & 0.000 & 0.000 & 0.000 \\
\hline \multicolumn{5}{|l|}{ Chronic disease or disability } \\
\hline None & 0.51 & 0.69 & 1.00 & 0.61 \\
\hline Limiting & 1.31 & 1.81 & 2.32 & 1.80 \\
\hline Non-limiting & 0.93 & 1.34 & 2.07 & 1.38 \\
\hline$p$ value $e^{\star \star}$ & 0.000 & 0.000 & 0.000 & 0.000 \\
\hline Total & 0.62 & 1.05 & 1.64 & 0.91 \\
\hline
\end{tabular}

* Mean for individuals who had or had not taken medicines;

$\star \star$ Test for comparison of means.

prescription was significantly more frequent among the elderly, women, those with bad selfrated health, and those with chronic disease or disability. For $87.0 \%$ of persons over 60 who had used medicines in the two weeks, all the medicines had been prescribed by a health professional. There was no significant difference in the proportions by number of household assets or size of the municipality.

Table 4 shows the proportion of individuals who had used some medicine in the previous two weeks, grouped by type. The highest pro- portion of utilization was in the group of analgesics, anti-inflammatory drugs, antipyretics, and muscle relaxants, with $22.1 \%$, and only about one-half $(51.0 \%)$ of the individuals using these medicines had done so under a medical prescription. The second largest proportion was assigned to the cardiovascular medicine group, with $14.0 \%$, nearly all of which $(99.0 \%)$ under a medical prescription. The third and fourth most widely used groups of medicines were "Hormones, other endocrine medicines, and contraceptives" and psychoactive drugs, respec- 
Distribution (\%) of individuals who had used medicines in the two week prior to the interview, by presence

of medical prescription, according to socio-demographic variables and self-rated health. Brazil, 2003.

\begin{tabular}{|c|c|c|c|c|c|c|}
\hline \multirow[t]{3}{*}{ Variable } & \multicolumn{3}{|c|}{ Medical prescription } & \multicolumn{2}{|c|}{ Total } & \multirow[t]{3}{*}{$p$ value } \\
\hline & $\begin{array}{l}\text { All prescribed } \\
\text { by physician }\end{array}$ & $\begin{array}{l}\text { At least one } \\
\text { medicine } \\
\text { prescribed }\end{array}$ & $\begin{array}{l}\text { None } \\
\text { prescribed }\end{array}$ & & & \\
\hline & $\%$ & $\%$ & $\%$ & $\mathrm{~N}$ & $\%$ & \\
\hline \multicolumn{7}{|l|}{ Sex } \\
\hline Male & 65.0 & 5.8 & 29.2 & 887 & 100.0 & 0.001 \\
\hline Female & 69.9 & 8.2 & 21.9 & 1.542 & 100.0 & \\
\hline \multicolumn{7}{|l|}{ Age group (years) } \\
\hline $18-39$ & 53.9 & 8.6 & 37.5 & 1.020 & 100.0 & 0.000 \\
\hline $40-59$ & 73.4 & 7.2 & 19.5 & 867 & 100.0 & \\
\hline 60 and over & 86.6 & 5.1 & 8.3 & 541 & 100.0 & \\
\hline \multicolumn{7}{|l|}{ Schooling } \\
\hline Incomplete fundamental & 73.5 & 5.8 & 20.7 & 1.343 & 100.0 & 0.000 \\
\hline Complete fundamental or more & 61.5 & 9.1 & 29.4 & 1.086 & 100.0 & \\
\hline \multicolumn{7}{|l|}{ Number of household assets } \\
\hline $0-3$ & 66.6 & 7.6 & 25.8 & 597 & 100.0 & NS \\
\hline $4-7$ & 69.8 & 6.8 & 23.4 & 1.333 & 100.0 & \\
\hline $8+$ & 65.1 & 8.4 & 26.5 & 474 & 100.0 & \\
\hline \multicolumn{7}{|l|}{ Size of municipality (inhabitants) } \\
\hline Up to 49,999 & 71.0 & 6.8 & 22.2 & 796 & 100.0 & NS \\
\hline $50,000-399,999$ & 69.6 & 5.9 & 24.4 & 795 & 100.0 & \\
\hline 400,000 or more & 63.9 & 9.1 & 27.0 & 837 & 100.0 & \\
\hline \multicolumn{7}{|l|}{ Self-rated health } \\
\hline Very good/Good & 56.7 & 8.2 & 35.2 & 1.033 & 100.0 & 0.000 \\
\hline Moderate & 74.5 & 6.6 & 18.9 & 1.060 & 100.0 & \\
\hline Very bad/Bad & 83.2 & 7.0 & 9.8 & 334 & 100.0 & \\
\hline \multicolumn{7}{|l|}{ Chronic disease or disability } \\
\hline None & 57.2 & 7.7 & 35.2 & 1.343 & 100.0 & 0.000 \\
\hline Limiting & 82.5 & 7.3 & 10.2 & 735 & 100.0 & \\
\hline Non-limiting & 81.1 & 6.1 & 12.9 & 328 & 100.0 & \\
\hline Total & 68.1 & 7.3 & 24.6 & 2.429 & 100.0 & - \\
\hline
\end{tabular}

* $\chi^{2}$ test for homogeneity of proportions.

tively, both with high prescription rates. Among the groups used by fewer than $5.0 \%$, gastrointestinal medicines and herbal medicines showed low prescription rates $(64.0 \%)$ as compared to the other groups.

The results in Table 5 indicate that of the 3,192 individuals who had medicines prescribed by a health professional at the last appointment, $87.0 \%$ had succeeded in obtaining all their medication. Among the 417 (13.0\%) who had medicines prescribed at the last appointment but who had not succeeded in obtaining all the medicines, $55.0 \%$ claimed that they could not pay and $13.0 \%$ that they had not found the medicines.

\section{Discussion}

According to the Brazilian WHS data, women use more medicines than men, as do the elderly. Among persons 60 years or older, the ones showing the highest use of medicines belong to the higher socioeconomic groups. This pattern 
Proportion (\%) of individuals who had used some medicine in the two weeks prior to the interview, grouped by type of medicine, and proportion (\%) of individuals who had used medicines with a medical prescription. Brazil, 2003.

\begin{tabular}{|c|c|c|c|c|}
\hline \multirow[t]{2}{*}{ Group of medicines } & \multicolumn{2}{|c|}{$\begin{array}{l}\text { Individuals who had } \\
\text { used medicines (\%) }\end{array}$} & \multicolumn{2}{|c|}{$\begin{array}{l}\text { Individuals who had used } \\
\text { medicines with medical } \\
\text { prescription, among all those } \\
\text { who had used medicines (\%) }\end{array}$} \\
\hline & $\mathrm{N}$ & $\%$ & $\mathrm{~N}$ & $\%$ \\
\hline $\begin{array}{l}\text { Analgesics, antipyretics, anti-inflammatory drugs, } \\
\text { and muscle relaxants }\end{array}$ & 1,103 & 22.1 & 567 & 51.4 \\
\hline Cardiovascular medicines & 673 & 13.5 & 667 & 99.0 \\
\hline Medicines acting on the respiratory tract & 159 & 3.2 & 116 & 73.0 \\
\hline Psychoactive drugs & 250 & 5.0 & 245 & 98.0 \\
\hline Hormones and other endocrine drugs and contraceptives & 301 & 6.0 & 292 & 97.0 \\
\hline Anti-infectious medicines & 145 & 2.9 & 122 & 84.1 \\
\hline Vitamins, minerals, and nutritional supplements & 121 & 2.4 & 95 & 77.9 \\
\hline Herbal medicines & 100 & 2.0 & 64 & 64.0 \\
\hline Anti-convulsive and anti-epileptic medicines & 48 & 1.0 & 48 & 100.0 \\
\hline Gastrointestinal medicines & 215 & 4.3 & 137 & 64.0 \\
\hline Other medicines & 282 & 5.6 & 258 & 91.5 \\
\hline
\end{tabular}

Table 5

Proportion (\%) of individuals who were not able to obtain all the medicines prescribed by the health professional in the last appointment, according to reported reason. Brazil, 2003.

\begin{tabular}{lrc}
\hline Reason & \multicolumn{2}{c}{$\%$} \\
\hline Could not pay & 55.0 & $(229 / 417)^{\star}$ \\
Did not find & 13.2 & $(55 / 417)$ \\
Did not believe it was necessary & 5.6 & $(23 / 417)$ \\
Improved without medication & 7.0 & $(29 / 417)$ \\
Other & 19.2 & $(80 / 417)$ \\
Total & 13.1 & $(417 / 3,192)^{\star \star}$ \\
\hline
\end{tabular}

* Percentage of individuals who were not able to obtain

all the medicines prescribed:

** Percentage of individuals who had medicines prescribed

in their last medical appointment.

coincides with the use of health services, as widely described in the literature 4,14 .

In association with advancing age, as expected, persons with chronic disease or disability use the most medicines. These are the same individuals who spend more on treatment. Brazilian WHS data show that $16.0 \%$ of persons with a disease and resulting limitation had to borrow money from a financial institution or sell objects to pay their medical care expenses 15. Likewise, a nationwide study in 1998 showed that mean monthly expenditure on medicines represented $23.0 \%$ of income for half of the Brazilian elderly population 16.

The results of the current analysis on the mean number of medicines used during the reference period by persons 60 years or older show the existence of a socioeconomic gradient in the use of medicines, regardless of which social status indicator is used. Use by the elderly is also greater in larger municipalities. In municipalities with more than 400 thousand inhabitants, the mean number of medicines used is close to two, consistent with the results of previous studies 17. Meanwhile, in small towns the mean number of medicines used was lower than the standard in other countries.

However, it is important to note that the analysis of use of medicines was limited to participants who kept some medicine at home. The fact that the individual may have used some medicine in the previous two weeks and not kept the package afterwards was an important limitation to the study.

Excessive use of medicines without a medical prescription in the wealthier classes has been attributed to the consumption of superfluous products, apparently increasing due to over-the-counter sales of certain pharmaceuticals in Brazil 10. Corroborating these findings, the survey showed that $22.0 \%$ had used medicines from the group of analgesics, anti-inflammatory drugs, antipyretics, and muscle relaxants in the previous two weeks, but that on- 
ly $51.0 \%$ of these products had been prescribed by a physician.

Interestingly, the percentage of use of medicines, categorized by their active ingredients, was similar to that found in a study on selfmedication in Brazil 18. Although the two studies have different methodologies, one with data collected in households (WHS) and the other with information collected in pharmacies, both showed that analgesics and anti-inflammatory drugs are the medicines most widely used without medical prescriptions.

In developed countries, although over-thecounter drug sales have expanded, thereby favoring self-medication, the rigid control established by regulatory agencies makes this practice less problematic than in Brazil. According to the Brazilian Association of the Pharmaceutical Industry (ABIFARMA), some 80 million Brazilians self-medicate. The inadequate supply of medicines and non-enforcement of manda- tory presentation of medical prescriptions, along with low overall schooling, are the most widely cited reasons for the high frequency of self-medication in Brazil 18. In an opinion article on the rational use of medicines, Bermudez 19 comments that the adequacy of prescription and utilization of drugs using scientificallybased criteria are the main current challenges for the SUS.

A positive finding of the Brazilian WHS was the large percentage of individuals (around 87.0\%) who succeeded in obtaining the majority of the medicines prescribed by a health professional at their last appointment. However, among those who failed to obtain their medication, lack of money was claimed as the most common reason, cited by more than half of the interviewees, indicating that difficulty in obtaining the necessary medicines for treatment is a problem that has still not been completely solved by the public health system.

\section{Resumo}

O presente estudo tem como objetivo caracterizar a utilização de medicamentos na população brasileira, por meio dos dados da Pesquisa Mundial de Saúde. Os medicamentos foram agrupados de acordo com o princípio ativo baseando-se em uma adaptação da lista padrão da Organização Mundial da Saúde. A análise contemplou as características das pessoas que guardam medicamentos em casa e que utilizaram medicamentos nas duas semanas anteriores à data da pesquisa segundo a presença de prescrição médica. Quase a metade dos participantes relatou uso no período de referência (49,0\%). Os indivíduos mais idosos, com maior riqueza, com doença de longa duração ou incapacidade e com auto-avaliação ruim da saúde guardam e utilizam medicamentos com maior freqüência. Entre os indivíduos que utilizaram medicamentos no periodo de referência, para 25,0\%, nenhum foi prescrito por médico. Dentre os indivíduos que tiveram prescrição de medicamentos no último atendimento, 13,0\% não conseguiram adquirir todos os medicamentos, sendo que 55,0\% alegaram que não puderam pagar. A maior proporção de utilização foi encontrada para o grupo dos analgésicos (22,0\%), sendo que somente $51,0 \%$ dos indivíduos que utilizaram esses medicamentos o fizeram com prescrição médica.

Medicamentos; Uso de Medicamentos; Prescrição de Medicamentos

\section{Contributors}

M. F. Carvalho was responsible for designing the content and drafting the text. A. R. P. Pascom was responsible for the data analysis. P. R. B. Souza Júnior participated in the data analysis and preparation of the tables. G. N. Damacena participated in the coding of information on medicines and classification of the active ingredients. C. L. Szwarcwald participated in the final draft of the article and the statistical data analysis, and coordinated the survey. 


\section{References}

1. Organización Mundial de la Salud. Perspectivas políticas sobre medicamentos de la OMS. Promoción del uso racional de medicamentos: componentes centrales. Geneva: Organización Mundial de la Salud; 2002.

2. Wannmacher L. Uso racional de medicamentos: medida facilitadora do acesso. In: Bermudez JAZ, Oliveira MA, Eshe A, organizadores. Acceso a medicamentos: derecho fundamental, papel del estado. Rio de Janeiro: Escola Nacional de Saúde Pública, Fundação Oswaldo Cruz; 2004. p. 91-101.

3. Smith D, Binet L, Bonnevie L, Hakokongas L, Meybaum, J. Desequilíbrio fatal: a crise de pesquisa e desenvolvimento de drogas para doenças negligenciadas. Genebra: Médicos Sem Fronteiras; 2001.

4. Miralles MA, Kimberlin CL. Perceived access to care and medication use among ambulatory elderly in Rio de Janeiro, Brazil. Soc Sci Med 1998; 46:345-55.

5. Secretaria de Políticas de Saúde, Ministério da Saúde. Política nacional de medicamentos 2001. Brasília: Ministério da Saúde; 2001. (Série C. Projetos, Programas e Relatórios 25).

6. D'Alessio R. Programa de medicamentos essenciais OPAS / OMS. In: Bermudez JAZ, Oliveira MA, Eshe A, organizadores. Acceso a medicamentos: derecho fundamental, papel del estado. Rio de Janeiro: Escola Nacional de Saúde Pública, Fundação Oswaldo Cruz; 2004. p. 41-4.

7. Conselho Nacional de Saúde. Diretrizes para uma política de medicamentos genéricos. http://www. datasus.gov.br/conselho/DOCUMENTOS/gen2. htm (accessed on Jan/2004).

8. Castro CGSO. Estudos de utilização de medicamentos: noções básicas. Rio de Janeiro: Editora Fiocruz; 2000.

9. Silveira GS, Osório RG, Piola SF. Os gastos das famílias com saúde. Ciênc Saúde Coletiva 2002; 7:719-13.
10. Rozenfeld S. Prevalência, fatores associados e mau uso de medicamentos entre idosos: uma revisão. Cad Saúde Pública 2003; 19:717-24.

11. World Health Organization. WHO model list of essential medicines. 2002. http://whqlibdoc.who.int/ hq/2002/a76618.pdf (accessed on 21/Oct/2005).

12. Dicionário de Especialidades Farmacêuticas. 20022003. http://www.epuc.com.br/def/ (accessed on Jan/2004).

13. Korolkovas A. Dicionário terapêutico Guanabara. Edição 2001/2002. São Paulo: Editora Guanabara Koogan; 2001.

14. Coelho Filho JM, Marcopito LF, Castelo A. Medication use patterns among elderly people in urban area in Northeastern Brazil. Rev Saúde Pública 2004 ; 38:557-64.

15. Szwarcwald CL, Viacava F, Vasconcellos MTL, Leal MC, Azevedo LO, Queiroz RSB, et al. O Brasil em números. Radis 2004; 23:14-33.

16. Lima-Costa MF, Barreto SM, Giatti L. Condições de saúde, capacidade funcional, uso de serviços de saúde e gastos com medicamentos da população idosa brasileira: um estudo descritivo baseado na Pesquisa Nacional por Amostra de Domicílios. Cad Saúde Pública 2003; 19:735-43.

17. Laukkanen P, Heikkinen E, Kauppinen M, Kallinen M. Use of drugs by non-institutionalized urban Finns born in 1904-1923 and the association of drug use with mood and self-rated health. Age Ageing 1992; 21:343-52.

18. Arrais PS, Coelho HL, Batista MC, Carvalho ML, Righi RE, Arnau JM. Profile of self-medication in Brazil. Rev Saúde Pública 1997; 31:71-7.

20. Bermudez J. Medicamentos: uma questão polêmica. Ciênc Hoje 2000; 27:60-2.

Submitted on 04/May/2005

Final version resubmitted on 21/Oct/2005

Approved on 21/Oct/2005 